\title{
Investigation of P53, HIPK-2 and EIF2S1 Genes Expression Changes Induced by in Vitro Gamma Radiation
}

\author{
In Vitro Olarak Gama Radyasyon ile İndüklenen P53, HIPK-2 ve \\ EIF2S1 Genlerinin Ekspresyon Değişikliklerinin Araştırılması
}

\author{
Research Article \\ Sibel Ünlü*, Emel Sağlar \\ Hacettepe University, Faculty of Science, Department of Biology, Molecular Biology Section, Ankara, Turkey.
}

\begin{abstract}
A B S TR ACT
n this study, we have investigated induction of P53, HIPK-2 and EIF2S1 genes after exposure to low doses gamma radiation by using the peripheral human lymphocytes. Gene expression changes were analyzed in quantitative real time polymerase chain reaction (QRT PCR) by using B2M as a reference gene. Whole blood samples of ten young, healthy and non-smoking donors were taken. All samples were divided in to five specimens and four of them were irradiated using constant gamma irradiation source (60Co) giving the dose rate of 0.0327 kGy/h while one sample used as control. Blood samples were exposed to $0.1 \mathrm{~Gy}, 0.5 \mathrm{~Gy}, 1 \mathrm{~Gy}$ and $3 \mathrm{~Gy} \gamma$-rays. Results were expressed in terms of the threshold cycle value (Ct) in REST 2009 (Relative Expression Software Tool V. 2.0.13) program and the difference between the CT values of the target gene and the reference gene was calculated. We found a linear dose-response relationship for P53, HIPK-2 and EIF2S1 genes. Results of the QRT PCR showed that three of the genes were up-regulated after radiation exposure. We concluded that P53, HIPK-2 and EIF2S1 genes can be promising for the assessment of gene expression changes in radiation exposure induced DNA damage.
\end{abstract}

\section{Key Words}

Gene expression; Ionizing radiation, QRT PCR.

\section{ÖZET}

u çalışmada periferal insan lenfositlerinde düşük doz gama radyasyon maruziyeti sonrası P53, HIPK-2 ve EIF2S1 genlerinin indüksiyonunu araştırılmıştır. Gen ekspresyon değişiklikleri, B2M referans gen olarak kullanılarak kantitafif gerçek zamanlı polimeraz zincir reaksiyonu ile (KRT PZR) değerlendirilmiştir. Bu amaçla genç, sağlıklı ve sigara içmeyen on bireye ait kan örnekleri toplanmıştır. Her birey için beş tüpe bölünen örneklerden ilki kontrol olarak ayrılmış diğer dördü sabit gama kaynağında (Co60) 0,0327 kGy/sa doz hızına göre hesaplanmış 0,1 Gy, 0.5 Gy, 1 Gy ve 3 Gy gama radyasyonuna maruz bırakıımıştır. Sonuçlar eşik değerinin aşıldığı döngü değerlerine (CT) göre REST 2009 (Relative Expression Software Tool V. 2.0.13) programında değerlendirilmiş, hedef genin ve referans genin CT değerleri arasındaki farklılıklara göre hesaplanmıştır. P53, HIPK2 ve EIF2S1 genleri için linear bir doz-cevap ilişkisi bulunmuştur. KRT PZR sonuçları bu üç geninin maruz kalınan dozlarda up-regüle olduğunu göstermiştir. Elde edilen sonuçlar P53, HIPK2 ve EIF2S1 genlerinin radyasyon maruziyeti sonrasında indüklenen DNA hasarında ki gen ekspresyon değişikliklerinin değerlendirilmesinde kullanılabileceğini göstermiştir.

\section{Anahtar Kelimeler}

Gene ekspresyonu, iyonize radyasyon, QRT PCR.

Article History: Received: Jan 31, 2016; Revised: Jul 21, 2016; Accepted: Jul 21, 2016; Available Online: Jul $31,2016$.

DOI: $10.15671 /$ HJBC.20164420578

Correspondence to: S. Ünlü, Hacettepe University, Faculty of Science, Department of Biology, Molecular Biology Section, Ankara, Turkey. 


\section{INTRODUCTION}

P adiation induced DNA damage may result in genomic instability. These damages stimulate signal transduction pathways inside the cell and can trigger a series of events for an appropriate DNA damage response, such as apoptosis and autophagy [1]. The effects of high dose radiations are well defined but the cell responses to low dose exposure remain to be determined [2]. It is known that ionizing radiation causes cellular responses and damages to cellular organelles, membranes and biomolecules, and as well exposure of DNA to ionizing radiation results in single-strand breaks, double-strand breaks, alkali-labile sites and oxidized bases $[3,4]$.

One of the pathways in the nucleus is ataxia-telangiectasia mutated (ATM)/P53 tumor suppressor pathway which is a major cellular mechanism in the cellular response to alterations in genomic integrity and in the activation of cell cycle checkpoints [5-7]. ATM is a damageactivated protein kinase and phosphorylates $P 53$ after irradiation. This phosphorylation causes transcriptional activation of $P 53$ and many genes are activated by $P 53$-dependent transcription $[5,8]$. Another pathway is the PERK-elF2alpha signaling pathway, which mediates the first response to endoplasmic reticulum stress [9]. The pattern of the genes in these pathways may be up or down regulated after irradiation. It was shown that genes such as the tumor suppressor P53, Homeodomain-interacting protein kinase-2 $(H I P K-2)$ and Eukaryotic translation initiation factor 2 subunit 1 (EIF2S1) contribute to stress responses to ionizing radiation $[6,10,11]$. In this study we aimed to evaluate the effects of lowdose gamma radiation on P53, HIPK-2 and EIF2S1 genes. In dose response studies while microarray studies are perfect tools for largescale screening, an accurate relationship between dose and the level of expression of various genes can only be validated with QRT-PCR [12]. We have used human lymphocytes and evaluated the genes expressions with quantitative real-time polymerase chain reaction (QRT PCR), which is a reliable and sensitive method.

\section{MATERIALS AND METHODS}

\section{In Vitro Whole Blood Sample Irradiation}

The whole blood samples of young, healthy and non-smoking donors were taken by venipuncture to five different tubes with lithium heparin. First tube of the samples was used as their own control and not irradiated. Other four tubes were irradiated using constant gamma irradiation source (60Co). According to $373 \mathrm{kGy} / \mathrm{hr}$ dose rate of the constant gamma irradiation source, $0.1 \mathrm{~Gy}$, $0.5 \mathrm{~Gy}, 1 \mathrm{~Gy}$ and $3 \mathrm{~Gy}$ were calculated and were given the four different tubes of the samples.

\section{RNA Extraction and CDNA Synthesis}

Lymphocytes were isolated from whole peripheral blood on a density gradient by using the Histopaque-1077 (Sigma). Total RNA was isolated from lymphocytes using an RNeasy plus mini kit (Qiagen) by following the manufacturer's protocol. RNA samples were quantified by GeneQuant 1300 spectrophotometer (GE Healthcare) at 260 and $280 \mathrm{~nm}$ and stored at $-80^{\circ} \mathrm{C}$ until further analysis.

CDNA was synthesized by using the QuantiTect ${ }^{\circledR}$ Reverse Transcription Kit (Qiagen) according to the manufacturer's protocol and the CDNA product was stored at $-20^{\circ} \mathrm{C}$. Primer and probe sets used for quantitative real-time PCR are listed in the Table 1. Reactions were performed in a $10 \mu \mathrm{l}$ reaction volume containing $1 \mu \mathrm{l}$ of cDNA, $5 \mu \mathrm{l} 2 \mathrm{x}$ QuantiFast Probe RT-PCR master mix (Qiagen), $1 \mu$ of each primer and 1 $\mu l$ of probe. Real-time PCR was performed in a RotorGene 6000 real-time PCR machine (Corbett Research, Sydney, Australia) with the 72-well rotor. Reaction conditions were as follows: $5 \mathrm{~min}$ $94^{\circ} \mathrm{C}$ initial denaturation, followed by 45 cycles of $10 \mathrm{~s}$ at $94^{\circ} \mathrm{C}, 20 \mathrm{~s}$ at $60^{\circ} \mathrm{C}$-a combined annealing and extension step.

\section{Statistical Analysis}

The comparative threshold cycle (CT) method for the relative quantification of gene expression was used. Results were expressed in terms of CT value in REST 2009 (Relative Exp ression Software Tool V. 2.0.13) program and the difference $(\Delta C T)$ 
Table 1. Real-time primer and probe sequences.

\begin{tabular}{|c|c|}
\hline Gene & Primer/Probe Sequences \\
\hline \multirow{3}{*}{ P53 } & Forward primer 5'- CATGAGCGCTGCTCAGATAG-3' \\
\hline & Reverse primer 5'-CCAGTGTGATGATGGTGAGG-3' \\
\hline & Probe 5'-FAM- CCCCTCCTCAGCATCTTATCCGAGTGG -BHQ1-3' \\
\hline \multirow{3}{*}{ HIPK2 } & Forward primer 5'- CCGGGACAAAGACAACTAGG -3' \\
\hline & Reverse primer 5'- СССТTCCAAATCTGTCGTC -3' \\
\hline & Probe 5'-FAM- CGTGACACGGACTCACCATATCCTTTG -BHQ1-3' \\
\hline \multirow{3}{*}{ EIF2S1 } & Forward primer 5'- GAACAGGCTTGGCAAAGAAG-3' \\
\hline & Reverse primer 5'- AGGCTTTGATGGGAGATTCA-3' \\
\hline & Probe 5'-HEX-GATCACTCCAGTGCACTCGA -BHQ1-3' \\
\hline
\end{tabular}

between the CT values of the target gene and the reference gene was calculated.

\section{RESULTS}

Peripheral human lymphocytes, which were proved to be sensitive to ionizing radiation and previously established as suitable biodosimeters, demonstrate a DNA damage response following the low dose ionizing radiation $[13,14]$. Real time PCR analysis showed that, P53, HIPK-2 and EIF2S1 genes expressions were increased after exposure to ionizing radiation in vitro. According to QRT- PCR results, a linear and reproducible upregulation was detected in the expression of $P 53$, HIPK-2 and EIF2S1 genes, which were detailed graphically in Figure 1. $C_{T}$ values were obtained and according to the Ratio $=\left(E_{\text {target }}\right)^{\Delta C P}$ target (controlsample)/( $\left.E_{\text {ref }}\right)^{\Delta C P}$ ref(control-sample), gene expression changes were calculated using REST 2009 software program and relative expressions of target genes were determined.

\section{DISCUSSION}

Irradiation of human cells to low dose ionizing radiation alters the gene expression profiles. In this study we aimed to demonstrate the transcriptional changes of P53, HIPK-2 and EIF2S1 genes caused by ionizing radiation in vitro and we observed a linear and reproducible up-regulation of P53, HIPK-2 and EIF2S1 genes. Our results suggest that following the irradiation, human lymphocyte cells responded to radiation. It is clear that some nuclear pathways are activated by low dose ionizing radiation [1]. ATM protein, the product of ATM gene mutated in ataxiatelangiectasia, is activated by DNA damage and may initiate cell cycle arrest by activating the P53 tumor suppressor protein, the product of a tumor suppressor gene. P53, which is known for its role as a transcription factor that regulates the expression of a wide range of stress response genes, is stabilized and activated in response to cellular stress and extremely sensitive to DNA damage $[15,16]$. The levels of $P 53$ increases and bounds its specific DNA sites in the genome after irradiation. By this binding some growth arrest genes are activated and on the other hand cell cycle progression genes are repressed. Blocking the progression of the cells from $\mathrm{G} 1$ to $\mathrm{S}$ phase and from $\mathrm{G} 2$ to mitosis after DNA damage may provide time to cell for repair [15]. These may explain the linear up-regulation of P53 gene. HIPK-2 also participates in cell cycle arrest and DNA repair/damage pathways. After DNA damage HIPK-2 phosphorylates P53 [17]. HIPK-2, which is an unstable protein in unstressed cells because it is constantly degraded through the ubiquitinproteasome system, is a protein kinase that interacts with numerous transcription factors as well as transcriptional regulators and stabilizes after ionizing radiation $[18,19]$. It is reported that ionizing radiation provokes HIPK-2 accumulation and activation [11]. HIPK2 is regulated after this activation by the DNA damage checkpoint kinase 


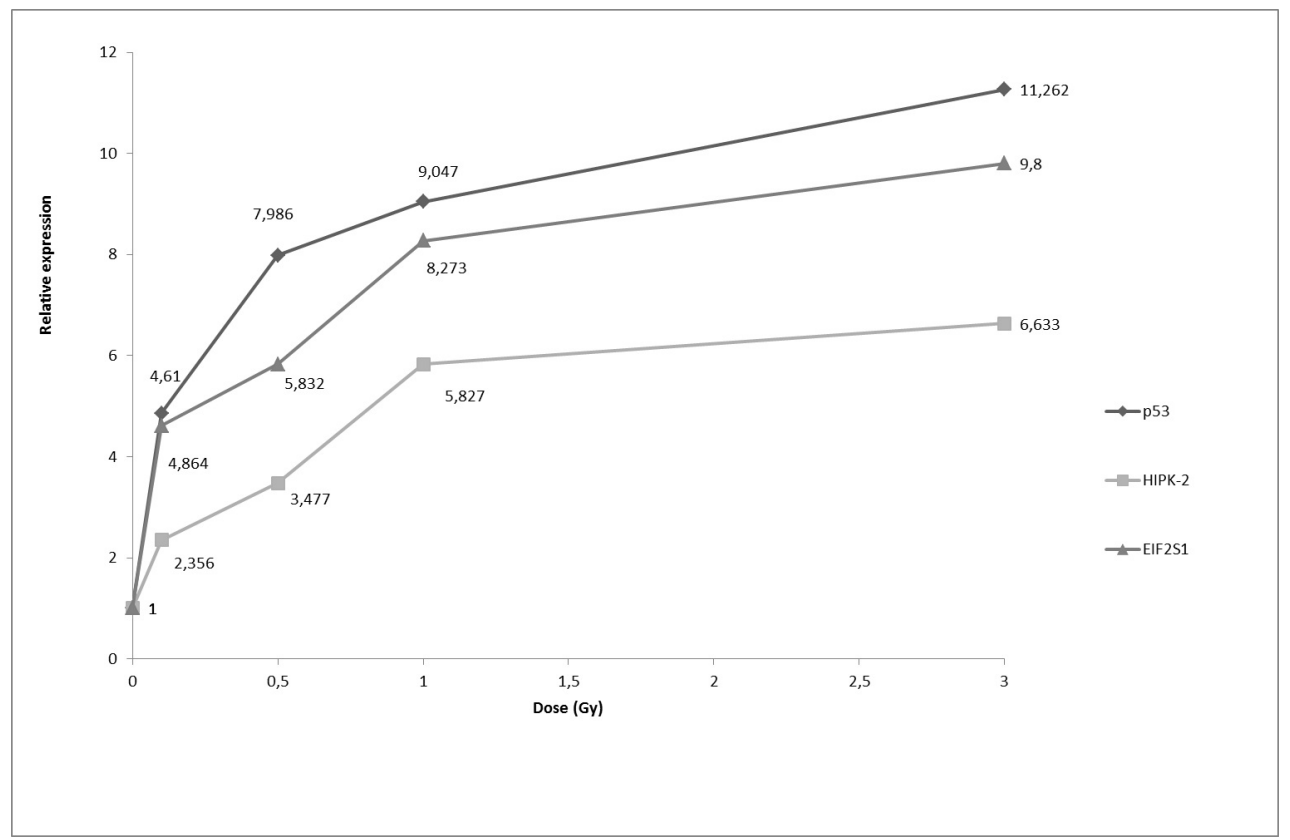

Figure 1. Relative expression ratios of $P 53$, HIPK-2 and EIF2S1 genes according to increasing ionizing radiation doses. Error bars represent 95\% confidence intervals.

ATM. Up-regulation of HIPK2 may explain with P53 serine-46 phosphorylation after ionizing radiation exposure. The PERK-eIF2 alpha signaling pathway is also activated following the DNA damage. PERK belongs to a family of eukaryotic translation initiation factor $2 \alpha$ (elF2) kinases and is a type I endoplasmic reticulum resident transmembrane protein that reside in the endoplasmic reticulum [20]. Zhang et al. were reported that PERK pathway has a stress sensor and involved in ER stress induced by radiation. They also have found that phosphorylated elF2alpha level increased in epithelial cell line [21]. It was shown that following the ionizing radiation exposure, PERK kinase is activated and after this activation it phosphorylates serine-51 of elf2alpha, which is its only identified target [22].

Gene expression studies on radiation induced DNA damage have led to insights into DNA repair and cell survival mechanisms. Our QRT PCR results suggest that relative levels of gene expression can be used efficiently to detect radiation-induced DNA damage related gene expression changes.

\section{ACKNOWLEDGMENTS}

The authors thank to Gamze Umulu for her contributions during the experimental stage. The authors declare that there is no conflict of interest that could be perceived as prejudicing the impartiality of this scientific work.

\section{References}

1. S. Braunstein, M.L. Badura, Q. Xi, S.C. Formenti, R.J. Schneider, Regulation of protein synthesis by ionizing radiation, Mol Cell Biol., 29 (2009) 5645-56.

2. Z. Goldberg, C.W. Schwietert, B. Lehnert, R. Stern, I. Nami, Effects of low-dose ionizing radiation on gene expression in human skin biopsies, Int J Radiat Oncol Biol Phys., 58 (2004) 567-74.

3. S. Gutierrez, E. Carbonell, P. Galofré, A. Creus, R. Marcos, The alkaline single-cell gel electrophoresis (SCGE) assay applied to the analysis of radiationinduced DNA damage in thyroid cancer patients treated with 1311, Mutat Res., 413 (1998) 111-9.

4. Z. Somosy, Radiation response of cell organelles, Micron., 31 (2000) 165-181.

5. J.Bolt, Q.N. Vo, W.J. Kim, A.J. McWhorter, J. Thomson, M.E. Hagensee, P. Friedlander, K.D. Brown, J. Gilbert, The ATM/P53 pathway is commonly targeted for inactivation in squamous cell carcinoma of the head and neck (SCCHN) by multiple molecular mechanisms, Oral Oncol., 41 (2005) 1013-20.

6. H.Y. Jiang, R.C. Wek, GCN2 phosphorylation of elF2alpha activates NF-kappaB in response to UV irradiation, Biochem J., 385 (2005) 371-80.

7. E.U. Kurz and S.P. Lees-Miller, DNA damage-induced activation of ATM and ATM-dependent signaling pathways. DNA Repair (Amst)., 3 (2004) 889-900. Review. 
8. K.D. Brown, C. Barlow, A. Wynshaw-Boris, Multiple ATM-dependent pathways: an explanation for pleiotropy, Am J Hum Genet., 64 (1999) 46-50.

9. K.W. Kim, L. Moretti, L.R. Mitchell, D.K. Jung, B. Lu, Endoplasmic Reticulum Stress Mediates RadiationInduced Autophagy via PERK-elF $2 \alpha$ in Caspase-3/7 Deficient Cells, Oncogene, 29 (2010) 3241-51.

10. S.A. Amundson, T.G. Myers, A.J. Jr Fornace, Roles for P53 in growth arrest and apoptosis: putting on the brakes after genotoxic stress, Oncogene, 17 (1998) 3287-99. Review.

11. I. Dauth, J. Krüger, T.G. Hofmann, Homeodomaininteracting protein kinase 2 is the ionizing radiationactivated $P 53$ serine 46 kinase and is regulated by ATM, Cancer Res., 67 (2007) 2274-9.

12. L. Roy, G. Gruel, A. Vaurijoux A, Cell response to ionising radiation analysed by gene expression patterns, Ann Ist Super Sanita., 45 (2009) 272-7. Review

13. M. Gamulin, N. Kopjar, M. Grgi, S. Rami, V. Bisof, V. Garaj-Vrhovac, Genome damage in oropharyngeal cancer patients treated by radiotherapy, Croat Med J., 49 (2008) 515-27.

14. V. Garaj-Vrhovac, G. Gajski, S. Miljanic, Sensitivity of the standard and Fpg-modified comet assay for the estimation of DNA damage in peripheral blood lymphocytes after exposure to gamma rays, Third European IRPA Congress, 2010.
15. C. Stecca, G.B. Gerber, Adaptive response to DNAdamaging agents: a review of potential mechanisms, Biochem Pharmacol., 55 (1998) 941-51.

16. D.W. Meek, Tumour suppression by P53: a role for the DNA damage response? Nature Reviews Cancer, 9 (2009) 714-23.

17. N. Bitomsky, T.G. Hofmann, Apoptosis and autophagy: Regulation of apoptosis by DNA damage signalling roles of P53, p73 and HIPK2. FEBS J., 276 (2009) 6074-83.

18. M.A. Calzado, F. Renner, A. Roscic, M.L. Schmitz, HIPK2: a versatile switchboard regulating the transcription machinery and cell death. Cell Cycle., 6 (2007) 139-43.

19. D. Sombroek and T.G. Hofmann, How cells switch HIPK2 on and off, Cell Death Differ., 16 (2009) 187-94.

20. A. Bertolotti, Y. Zhang, L.M. Hendershot, H.P. Harding, D. Ron, Dynamic interaction of BiP and ER stress transducers in the unfolded-protein response, Nat Cell Biol., 2 (2000) 326-332.

21. B. Zhang, Y. Wang, X. Pang, Y. Su, G. Ai, T. Wang, ER stress induced by ionising radiation in IEC- 6 cells, Int J Radiat Biol., 86 (2010) 429-35.

22. E. Lai, T. Teodoro, A. Volchuk, Endoplasmic reticulum stress: signaling the unfolded protein response. Physiology (Bethesda), 22 (2007) 193-201. 
